\title{
Polymorphisms in estrogen receptors predict the risk of male infertility: a meta-analysis
}

\author{
Tian-Fu Li, Qiu-Yue Wu, Cui Zhang, Wei-Wei Li, Na Li, Ying-Xia Cui, Xiao-Jun Li and Xin-Yi Xia*
}

\begin{abstract}
Background: Estrogen receptors play an important role in mediating estrogen action on target tissues, and the estrogen is relevant to male infertility. Single nucleotide polymorphisms (SNPs) in estrogen receptors may be associated with the risk of male infertility. A variety of case control studies have been published evaluating this association. However, the accumulated studies have shown inconsistent conclusions.

Methods: To further determine the potential association between the four common SNPs (rs2234693, rs9340799, rs1256049 and rs4986938) in estrogen receptors gene and male infertility, this meta-analysis was performed according to the 10 published case control studies. The odds ratio (OR) and 95\% confidence interval (Cl) were used to evaluate the strength of the associations.
\end{abstract}

Results: It was revealed that the sub-group analysis by the ethnicity, for the rs 2234693 , a significant association in the comparison of CC vs. TT (OR=0.61, 95\% Cl: 0.40-0.93), CT vs. $\Pi$ ( $(\mathrm{OR}=0.67,95 \% \mathrm{Cl}: 0.49-0.93)$ and CC + CT vs. $T$ $(\mathrm{OR}=0.66,95 \% \mathrm{Cl}: 0.49-0.89)$ in the Asian population with male infertility. For rs9340799 polymorphism, increased risks were observed for the comparison of $\mathrm{AA}$ vs. $\mathrm{GG}(\mathrm{OR}=1.75,95 \% \mathrm{Cl}: 1.15-2.68)$ and $\mathrm{AA}$ vs. $\mathrm{GA}+\mathrm{GG}(\mathrm{OR}=1.38$, 95\% Cl: 1.02-1.88). For rs 1256049 polymorphism, the comparison of the GA vs. GG (OR=1.52, 95\% Cl: 1.00-2.31) and $\mathrm{AA}+\mathrm{GA}$ vs. $\mathrm{GG}(\mathrm{OR}=1.74,95 \% \mathrm{Cl}: 1.03-2.94)$, also increased risks present in Asian and Caucasian population, respectively.

Conclusions: The rs2234693C allele was associated with the decreased risk for male infertility; however, the rs9340799AA genotype and the rs1256049GA genotype were associated with an increased risk for male infertility.

Keywords: Male infertility, Polymorphisms, Estrogen receptors

\section{Background}

Male infertility is an important cause of couple's inability to bear children in $20 \%$ to $25 \%$ of total cases and the etiology of nearly half of the cases remains idiopathic $[1,2]$. Approximately $15 \%$ of male infertile cases, genetic factors, including chromosomal aberrations and single gene mutations, may result in spermatogenic failure and sperm dysfunction [3,4]. The traditional view of estradiol as the 'female' hormone and of testosterone as the 'male' hormone has been challenged due to the increased interest in elucidating the role of estrogen in males [5]. Estrogens are produced in the male reproductive system by Sertoli cells, Leydig cells, and germ cells [6,7]. In addition, studies revealed that estrogens reduce testosterone production from

\footnotetext{
*Correspondence: xinyixia78@gmail.com

Department of Reproduction and Genetics, Institute of Laboratory Medicine, Jinling Hospital, Nanjing University School of Medicine, Nanjing 210002, Jinling Hospi
PR China
}

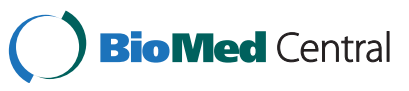

(c) 2014 Li et al.; licensee BioMed Central Ltd. This is an Open Access article distributed under the terms of the Creative Commons Attribution License (http://creativecommons.org/licenses/by/4.0), which permits unrestricted use, distribution, and reproduction in any medium, provided the original work is properly credited. The Creative Commons Public Domain Dedication waiver (http://creativecommons.org/publicdomain/zero/1.0/) applies to the data made available in this article unless otherwise stated.
Leydig cells and reduce Sertoli cell numbers in adult when they are given during development $[8,9]$. The estrogens can also disrupt fetal Leydig cell development, inhibit apoptosis of human postmeiotic germ cells, and increase spermatogonial number per testis [8-12]. The physical functions of estrogens were involved in the estrogen receptors (ERs). Moreover, ERs are members of the nuclear receptor (NR) superfamily that mediates the pleiotropic effects of estrogen in a diverse range of developmental and physiological processes, playing an important role in mediating estrogen action on target tissues [13,14].

ERs have been identified to be two subtypes of ER $\alpha$ and ER $\beta$. ER $\alpha$ is a 595-amino acid protein [15] encoded by the ERs 1 gene on chromosome $6 \mathrm{q} 25$, and $E R \beta$ is a 530-amino acid protein [16] which encoded by the ERs2 gene on chromosome 14q22-24. [17]. Genetic screening for the ER $\alpha$ gene locus has revealed several polymorphic 
sites [18], and two polymorphisms located in ER $\alpha$ intron 1 ( $\mathrm{T} / \mathrm{C}$ transition, rs2234693) and in $50 \mathrm{bp}$ downstream of the former one (G/A transition, rs9340799) have been widely concerned. In addition, the ER $\beta$ genes have been described with two silent G/A polymorphisms (rs1256049 and rs4986938) [19]. To date, epidemiological studies have been carried out to evaluate the association between ER polymorphisms and male infertility. However, the results remain inconsistent (Table 1) [5,7,19-26]. In order to get a more precise estimation of the association between polymorphisms in ERs and risk of male infertility, this metaanalysis was performed based on ten eligible previously published studies.

\section{Methods}

\section{Identification and eligibility of studies}

To identify all articles that examined the association of ERs polymorphisms with male infertility, a comprehensive systematic bibliographic search through the medical databases PUBMED, attempting to cover all medical papers published between 1950 and 2013, using the following keywords and subject terms: "male infertility", "polymorphism" and "estrogen receptors" or "ERs". The synonyms of polymorphism (rs2234693, rs9340799, rs1256049, and rs4986938) were also used as the keywords in the search. The studies were excluded if they were not English language papers or human subject. References in retrieved articles were screened in which case reports, meta-analyses and review articles were excluded. In addition, studies were identified by a manual search of the references lists of reviews and retrieved studies. All the studies were included if they met the following criteria: (I) about the rs2234693, rs9340799, rs1256049, and rs4986938 polymorphisms and male infertility, (II) from a case control study, (III) genotype frequencies could be derived. The reasons for exclusion of articles were listed in the Additional file 1: Text S1.

\section{Data extraction}

Two authors (Tian-Fu Li and Qiu-Yue Wu) extracted all data independently that met the inclusion criteria and reached the consensus for any controversy. The main characteristics of the enrolled studies were listed in the Table 1, including: (I) the first author's last name, (II) year of publication, (III) ethnicity, (IV) source of control groups (population- or hospital-based controls), (V) genotyping methods, (VI) the polymorphism sites, (VII) characteristics of studies, (VIII) Case/Control counts, (IX) Hardy-Weinberg equilibrium in the controls. Data were extracted separately for each ethnic groups categorized as Caucasian and Asian. However, no African was identified in this study.

\section{Statistical analysis}

The risk of male infertility associated with the four polymorphisms of the ERs gene was estimated for each study by odds ratio (OR), together with its 95\% confidence interval (CI), respectively. The four polymorphisms were evaluated for the associations with male infertility susceptibility based on four genetic models. To contrast, the wild-type homozygote (WW), we first estimated the risk of the rare allele homozygote (RR) and heterozygous (WR) genotypes on infertility, then evaluated the risk of infertility under a dominant model ( $R R+W R$ vs. WW). In addition, recessive model associations were also estimated (RR vs. WR + WW). Moreover, stratified analyses were also performed by ethnicity (Asian and Caucasian). The statistical significance of the pooled OR was determined with the Z-test and a P-value of $<0.05$ was considered significant. Heterogeneity across the studies was evaluated by Chi-square test based on $Q$ test [27] and was considered significant if $P<0.05$.A fixed-effect model using the Mantel-Haenszel method and a randomeffects model using the DerSimonian and Laird method were used to pool the results [28]. In addition, the fixedeffect model was used as well when there was no heterogeneity across results of the studies, or the random-effect model. Moreover, a sensitivity analysis, by which a single study in the meta-analysis was deleted each time to determine the influence of the individual data set to the overall pooled OR, was performed to assess the stability of the results. To test the publication bias, Funnel plots and Egger's linear regression test were applied [29]. Hardy-Weinberg equilibrium in the controls of each study was calculated using a web-based program [30]. All statistical tests for this meta-analysis were performed with STATA version 10.0 (Stata Corporation College Station, TX, USA).

\section{Results}

\section{Characteristics of studies}

A total of 10 eligible case control studies with the publication dates ranged from 2002 to 2013 met the prespecified inclusion criteria (shown in the Figure 1), including five studies of Asian population [19-21,23,24] and five studies of Caucasian population $[5,7,22,25,26]$. To determine the SNPs, two different genotyping methods such as PCR-RFLP [5,19-26] and TaqMan assays [7] were applied. All subjects were received comprehensive andrological examination, and the patients were divided into three types: oligozoospermia (sperm count $<20 \times 10^{6} / \mathrm{mL}$ ), azoospermia and oligoasthenoteratozoospermic (OAT). The studies' exclusion criteria and inclusion criteria were listed in the Table 1. In addition, the sources of controls in these studies were mainly population-based. The distribution of genotypes in the controls of all studies was consistent with Hardy-Weinberg equilibrium except for the 
Table 1 Summary of published studies included

\begin{tabular}{|c|c|c|c|c|c|c|c|c|}
\hline Author & Year & Race & $\begin{array}{l}\text { Source } \\
\text { of control }\end{array}$ & Method & $\begin{array}{l}\text { Polymorphism } \\
\text { sites }\end{array}$ & Characteristics of study patients & Case/control counts & $\begin{array}{c}\text { HWE } \\
\text { (Control) }\end{array}$ \\
\hline Meng [19] & 2013 & Asian & PB & PCR-RFLP & $\begin{array}{l}\text { rs2234693, } \\
\text { rs9340799, } \\
\text { rs1256049, } \\
\text { rs4986938 }\end{array}$ & $\begin{array}{c}\text { Age: } 25-38 \text { years (mean age } 32.1 \pm 5.2 \text { years). Exclusion criteria: } \\
\text { abnormal karyotypes, deletions of the Y chromosome, orchitis, } \\
\text { varicocele, cryptorchidism, congenital bilateral absence of the vas } \\
\text { deferens, hypogonadotropic hypogonadism, and iatrogenic } \\
\text { infertility. }\end{array}$ & $\begin{array}{c}\text { TT:83/82, CT:96/126, CC:25/44; AA:151/ } \\
\text { 148, AG:42/89,GG:11/15; GG:103/127, } \\
\text { AG:91/102, AA:10/23; GG:155/193, } \\
\text { AG:41/48, AA:8/11 }\end{array}$ & $\begin{array}{l}0.712,0.793 \\
0.699,0.001\end{array}$ \\
\hline Zalata [5] & 2013 & Caucasian & PB & PCR-RFLP & $\begin{array}{l}\text { rs2234693, } \\
\text { rs9340799 }\end{array}$ & $\begin{array}{l}\text { Inclusion criteria: same ethnic origin (Caucasians). Exclusion } \\
\text { criteria: varicocele, hormonal therapy, hypogonadism, smoking, Y } \\
\text { chromosome deletions and karyotype abnormalities. The ages of } \\
\text { were not shown in the article. }\end{array}$ & $\begin{array}{c}\text { ТT:33/14, CT:32/27, CC:16/19; AA:28/8, } \\
\text { AG:36/32, GG: } 17 / 20\end{array}$ & $0.468,0.389$ \\
\hline Ogata [20] & 2012 & Asian & PB & PCR-RFLP & rs1256049 & $\begin{array}{c}\text { Age: } 32-52 \text { years (median } 41.0 \text { years). Inclusion criteria: no } \\
\text { extragenital anomalies, seminal tract obstruction, varicocele, Y } \\
\text { chromosomal microdeletion, or retrograde ejaculation; normal } \\
\text { karyotypes. }\end{array}$ & GG:68/64, AG:49/45, AA:8/10 & 0.604 \\
\hline Bianco [7] & 2011 & Caucasian & PB & $\begin{array}{l}\text { TaqMan } \\
\text { assays }\end{array}$ & $\begin{array}{l}\text { rs2234693, } \\
\text { rs9340799, } \\
\text { rs1256049, } \\
\text { rs4986938 }\end{array}$ & $\begin{array}{c}\text { Age: } 36.1 \pm 6.5 \text { years. Exclusion criteria: chromosome anomalies, } \\
\text { azoospermia factor (AZF) microdeletions, smoking, alcoholism, } \\
\text { occupation, varicocele, and cryptorchidism. }\end{array}$ & $\begin{array}{c}\text { Tा:30/37, CT:93/111, CC:64/68; AA:80/ } \\
\text { 100, AG:79/88, GG:20/28; GG:172/201, } \\
\text { AG:15/15, AA:0/0; GG:43/28, AG:60/103, } \\
\text { AA:84/85 }\end{array}$ & $\begin{array}{l}0.468,0.221 \\
0.597,0.712\end{array}$ \\
\hline Safarinejad [21] & 2010 & Asian & PB & PCR-RFLP & $\begin{array}{l}\text { rs2234693, } \\
\text { rs9340799, } \\
\text { rs1256049, } \\
\text { rs4986938 }\end{array}$ & $\begin{array}{l}\text { Age: } 31.6 \pm 4.8 \text { years (range } 25-40 \text { years). Inclusion criterion: two } \\
\text { years with no reason for their infertility. Exclusion criteria: } \\
\text { varicocele or testicular torsion, urinary tract infections, } \\
\text { endocrinopathy, karyotype anomalies, Y-chromosome } \\
\text { microdeletions, use of drugs, leukocytospermia, a BMl of } \\
30 \mathrm{~kg} / \mathrm{m} 2 \text { or greater. }\end{array}$ & $\begin{array}{c}\text { TT:49/33, CT:70/86, CC:45/45; AA:62/41, } \\
\text { AG:77/95, GG:25/28; GG:142/152, } \\
\text { AG:21/8, AA:1/4; GG:65/80, AG:82/63, } \\
\text { AA:17/21 }\end{array}$ & $\begin{array}{l}0.486,0.034 \\
0.000,0.132\end{array}$ \\
\hline Lazaros [22] & 2010 & Caucasian & PB & PCR-RFLP & $\begin{array}{l}\text { rs2234693, } \\
\text { rs9340799, } \\
\text { rs } 1256049 \\
\text { rs4986938 }\end{array}$ & $\begin{array}{l}\text { Age: } 33.2 \pm 67.5 \text { years. Exclusion criteria: hypogonadotropic } \\
\text { hypogonadism, obstructive syndromes of the seminal tract, } \\
\text { microdeletions of the } Y \text { chromosome, karyotypic abnormalities. }\end{array}$ & $\begin{array}{l}\text { TT:6/20, CT:14/40, CC:9/25; AA:5/13, } \\
\text { AG:13/43, GG:11/29; GG:26/80, AG:3/5, } \\
\text { AA:0/0; GG:7/17, AG:12/36, AA:10/32 }\end{array}$ & $\begin{array}{l}0.609,0.652 \\
0.779,0.246\end{array}$ \\
\hline Khattri [23] & 2007 & Asian & PB & PCR-RFLP & rs1256049 & $\begin{array}{l}\text { Age: } 23.24 \pm 2.06 \text { years. Exclusion criteria: obstruction, } \\
\text { endocrinological defect, injuries, karyotypic abnormality, } \\
\text { Y-chromosome microdeletions. }\end{array}$ & GG:397/231, AG:46/21, AA:0/0 & 0.490 \\
\hline Omrani [24] & 2005 & Asian & PB & PCR-RFLP & $\begin{array}{l}\text { rs1256049, } \\
\text { rs4986938 }\end{array}$ & $\begin{array}{l}\text { Exclusion criteria: genetic causes of infertility, such as Klinefelter } \\
\text { syndrome or Ychromosome microdeletions. The ages of patients } \\
\text { were no shown in the article. }\end{array}$ & $\begin{array}{c}\text { GG:103/194, AG:17/9, AA:0/1; GG:51/86, } \\
\text { AG:57/88,AA:12/30 }\end{array}$ & $0.023,0.339$ \\
\hline Aschim [25] & 2005 & Caucasian & PB & PCR-RFLP & $\begin{array}{l}\text { rs1256049, } \\
\text { rs4986938 }\end{array}$ & $\begin{array}{l}\text { Exclusion criteria: Klinefelter syndrome or Y-chromosome } \\
\text { microdeletions, a history of cryptorchidism were excluded. } \\
\text { The ages of patients were no shown in the article. }\end{array}$ & $\begin{array}{c}\text { GG:92/177, AG:14/8, AA:0/1; GG:11/82, } \\
\text { AG:48/79, AA:47/25 }\end{array}$ & $0.015,0.394$ \\
\hline Kukuvitis [26] & 2002 & Caucasian & PB & PCR-RFLP & $\begin{array}{l}\text { rs2234693, } \\
\text { rs9340799 }\end{array}$ & $\begin{array}{l}\text { Exclusion criteria: any known aetiologies (varicocele, infections of } \\
\quad \text { accessory glands, cryptorchidism, homozygous form of } \\
\text { B-thalassemia). The ages of patients were no shown in the article. }\end{array}$ & $\begin{array}{c}\text { Tा:38/18, CT:38/25, CC:33/21; AA:30/10, } \\
\text { AG:45/28, GG:34/26 }\end{array}$ & $0.083,0.594$ \\
\hline
\end{tabular}




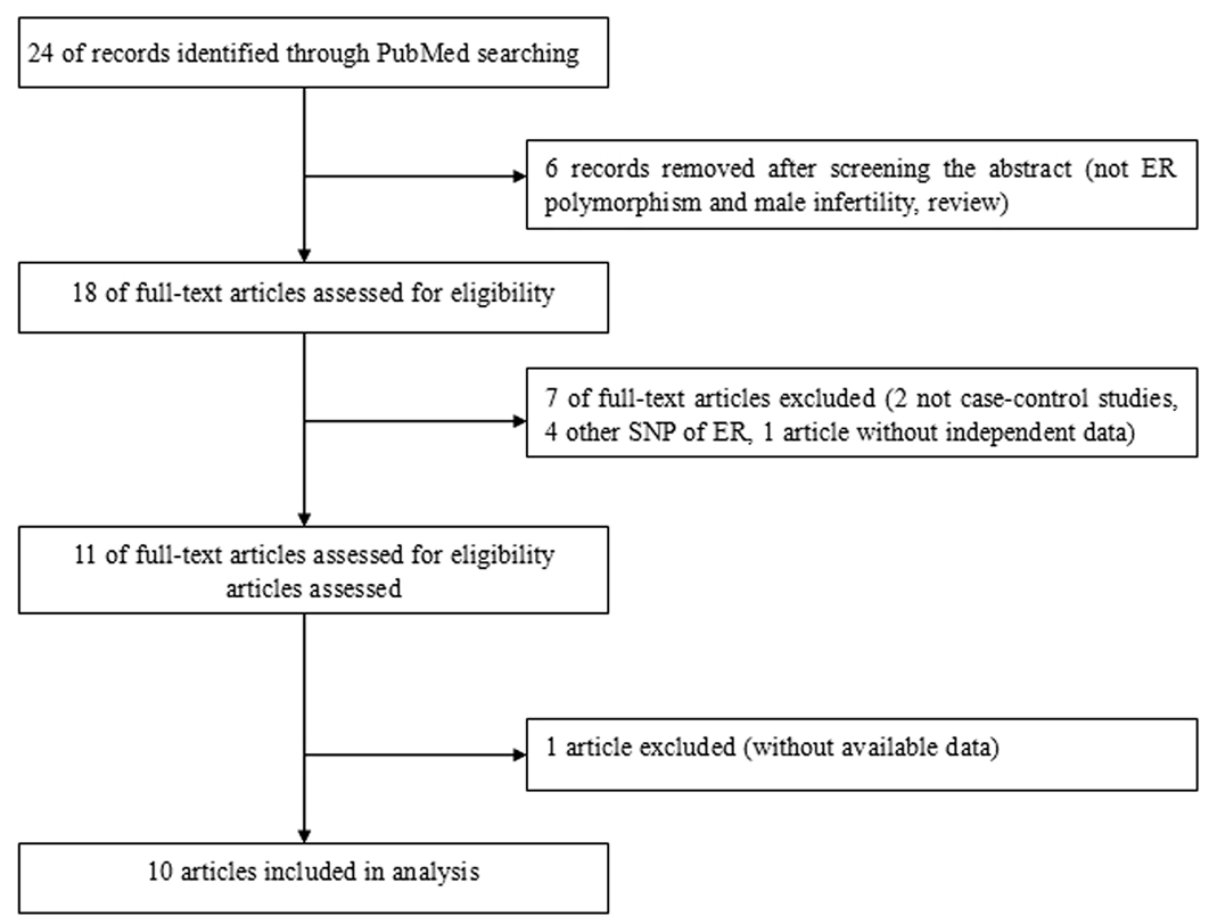

Figure 1 Flow chart of studies identified with inclusion and exclusion criteria.

study [19] in rs4986938, the study [21] in rs9340799 and rs1256049, study [24] in rs 1256049 and study [25] in rs1256049, which were tested in the sensitivity analyses.

\section{Quantitative synthesis}

Wide variation of four polymorphisms allele frequencies across different ethnicities was observed. For rs2234693, the frequency of $\mathrm{T}$ allele was 53.13\% (95\% CI: 49.7456.52) in the Asian controls, which was higher than that in Caucasian controls 44.82\% (95\% CI: 41.48-48.16) as shown in Figure 2A. For rs9340799, the frequency of G allele in the Asian controls (32.45\%, 95\% CI: 29.27-35.63) was lower than that in Caucasian controls (46.71\%, 95\% CI: 43.36-50.06) as shown in Figure 2B. In Figure 2C, we could find that the frequency of $G$ allele for the rs1256049 in the Asian controls (87.34\%, 95\% CI: 85.88-88.81) was lower than which in Caucasian controls (96.92\%, 95\% CI: 95.82-98.02). In contrast, the frequency of $\mathrm{G}$ allele in Caucasian controls $(48.46 \%$, 95\% CI: 45.32-51.60) was lower than that in Asian group (73.39\%, 95\% CI: 70.93-75.85) for the rs4986938 in Figure 2D.

For rs2234693 polymorphism, significant differences were observed for the comparison of CC vs. TT, CT vs. TT and CC + CT vs. TT. Sub-group analysis by the ethnicity revealed a significant association in the comparison of CC vs. TT $(\mathrm{OR}=0.61,95 \% \mathrm{CI}$ : 0.40-0.93,
$\left.P_{\text {heterogeneity }}=0.670\right), \mathrm{CT}$ vs. TT $(\mathrm{OR}=0.67,95 \% \mathrm{CI}$ : $\left.0.49-0.93, P_{\text {heterogeneity }}=0.358\right), \mathrm{CC}+\mathrm{CT}$ vs. TT $(\mathrm{OR}=$ $0.66,95 \%$ CI: $\left.0.49-0.89, P_{\text {heterogeneity }}=0.593\right)$ and $\mathrm{C}$ alleles vs. $\mathrm{T}$ alleles $\left(\mathrm{OR}=0.78,95 \% \mathrm{CI}: 0.64-0.96, P_{\text {heterogeneity }}=\right.$ 0.681 ) in the Asian population, as summarized in Table 2.

For rs9340799 polymorphism, increased risks were observed for the comparison of AA vs. GG and AA vs. GA + GG. Sub-group analysis by ethnicity revealed increased risks (AA vs. GG: OR $=1.75,95 \% \mathrm{CI}$ : 1.15 2.68, $P_{\text {heterogeneity }}=0.174 ;$ AA vs. GA + GG: $\mathrm{OR}=1.38$, 95\% CI: $\left.1.02-1.88, P_{\text {heterogeneity }}=0.062\right)$ in the Caucasian population, also for the AA vs. GA + GG and A alleles vs. $G$ alleles, a significant association was observed in Asian population $\left(\mathrm{OR}=1.93,95 \% \mathrm{CI}: 1.42-2.62, P_{\text {heterogeneity }}=\right.$ 0.768; $\mathrm{OR}=1.49,95 \% \mathrm{CI}: 1.18-1.87, P_{\text {heterogeneity }}=0.375$ ) as summarized in Table 3.

For rs1256049 polymorphism, significant differences were observed for the comparison of GA vs. GG, AA + GA vs. GG and AA vs. GA + GG. For the comparison of the GA vs. GG, AA + GA vs. GG, increased risks present in Asian and Caucasian population, respectively (GA vs. GG: $\mathrm{OR}=1.52,95 \% \mathrm{CI}: 1.00-2.31, P_{\text {heterogeneity }}=0.038 ; \mathrm{AA}+$ GA vs. GG: $\mathrm{OR}=1.74,95 \% \mathrm{CI}: 1.03-2.94, P_{\text {heterogeneity }}=$ 0.275 ). All data were concluded in the Table 4 . In contrast, a decreased risk was also observed for the comparison AA vs. $\mathrm{GA}+\mathrm{GG}\left(\mathrm{OR}=0.55,95 \% \mathrm{CI}: 0.31-0.97, P_{\text {heterogeneity }}=\right.$ 0.818) in Asian population. For the rs4986938, there was 

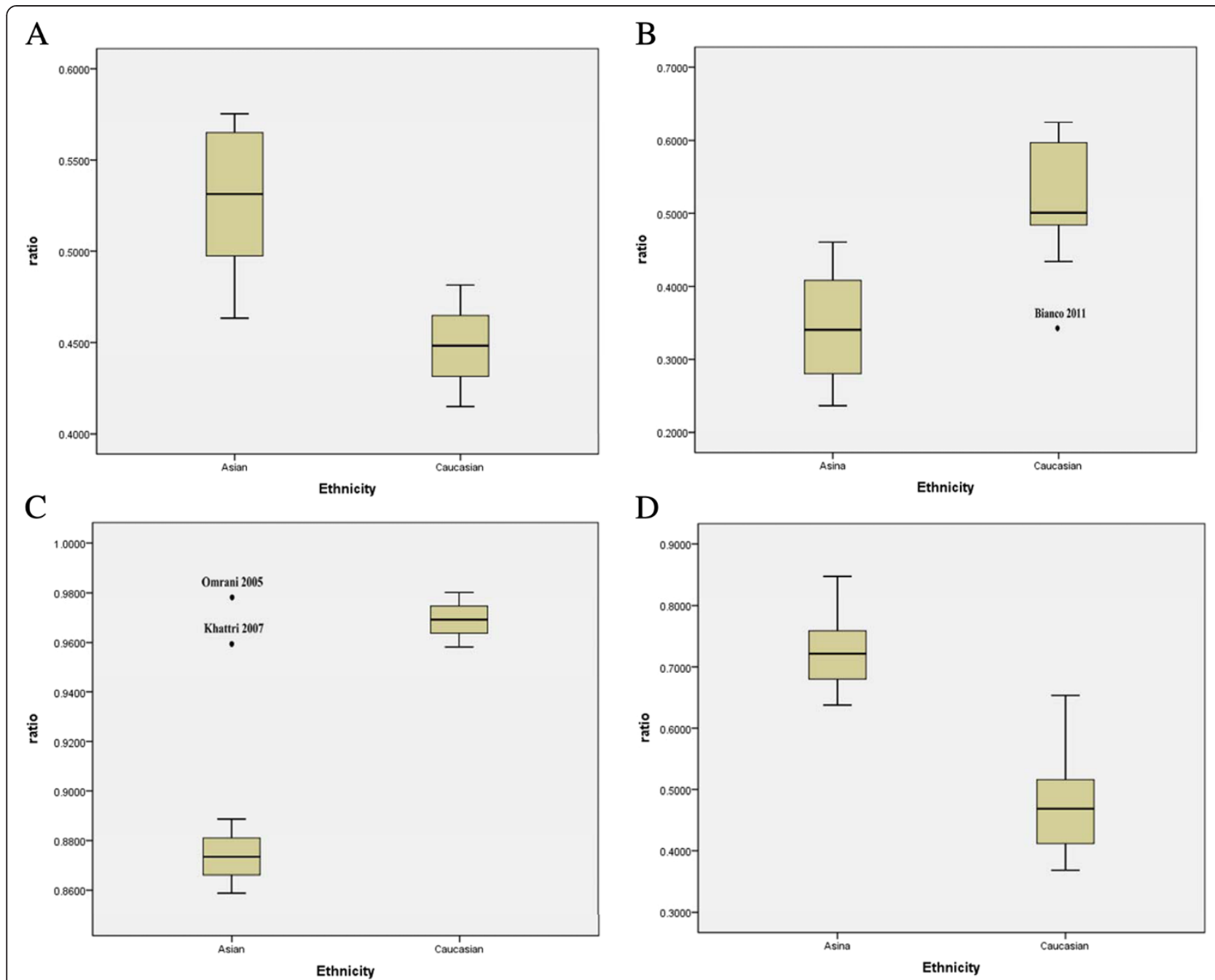

Figure 2 The allel frequencies of the four polymorphisms in the controls may vary by ethnicity. (A) rs2234693, (B) rs9340799, (C) rs 1256049 , (D) rs4986938. Star or dot denotes outliers.

no significant association observed in all comparisons (data were not shown).

\section{Test of heterogeneity}

Among the four polymorphisms, a significant heterogeneity was apparent among heterozygote comparison for the rs1256049 (GA vs. GG: $P_{\text {heterogeneity }}=0.047$ ) (Figure 3). Two studies [7,19] were identified to contribute to substantial heterogeneity, and it was decreased when the study was removed respectively $(P=0.065$, $P=0.075)$. Sensitivity analysis revealed that the two independent studies $[7,23]$ were the main cause of heterogeneity for the rs1256049. Heterogeneity was decreased when these studies were removed (GA vs. GG: $P_{\text {heterogeneity }}=$ $\left.0.320, I^{2}=14.7 \%\right)$. Although the genotype distributions in four studies did not follow Hardy-Weinberg equilibrium, the corresponding pooled ORs were not materially altered by excluding the studies.

\section{Publication bias}

Begg's funnel plot and Egger's test were performed to assess the publication bias of the currently available literature. For the rs2234693, rs9340799 and rs4986938, the shape of the funnel plots did not reveal any evidence of obvious asymmetry in all comparison models. Then, the Egger's test was used to provide statistical evidence for funnel plot symmetry. The results also did not show any evidence of publication bias. However, for the rs1256049, as shown in the Figure 4, the shape of the funnel plots seemed asymmetrical in the heterozygote and dominant comparisons, suggesting the presence of publication bias. Then, the Egger's tests were adopted to provide statistical evidence of funnel plot asymmetry. As expected, the results showed obvious evidence of publication bias $(t=2.53, P=0.044$ for GA vs. GG; $t=2.71, P=0.035$ for AA + GA vs. GG). To adjust for this bias, a trim-andfill method developed by Duval and Tweedie [31] was 
Table 2 Stratification analyses of genetic susceptibility of rs2234693 polymorphism to male infertility

\begin{tabular}{|c|c|c|c|c|c|c|c|c|c|c|c|c|c|c|c|c|}
\hline \multirow[t]{2}{*}{ Category } & \multirow{2}{*}{$\begin{array}{l}\text { Cases/ } \\
\text { controls }\end{array}$} & \multicolumn{3}{|c|}{ CC vs. TT } & \multicolumn{3}{|c|}{ CT vs. TT } & \multicolumn{3}{|c|}{$\mathrm{CC}+\mathrm{CT}$ vs. TT } & \multicolumn{3}{|c|}{$\mathrm{CC}$ vs. $\mathrm{CT}+\mathrm{TT}$} & \multicolumn{3}{|c|}{$\mathrm{C}$ allele vs. $\mathrm{T}$ allele } \\
\hline & & $\mathrm{OR}(95 \% \mathrm{Cl})$ & $P^{\mathrm{a}}$ & $I^{2}$ & $\mathrm{OR}(95 \% \mathrm{Cl})$ & $P^{a}$ & $\overline{1^{2}}$ & $\mathrm{OR}(95 \% \mathrm{Cl})$ & $P^{\mathrm{a}}$ & $I^{2}$ & OR(95\% Cl) & $P^{\mathrm{a}}$ & $I^{2}$ & OR(95\% Cl) & $P^{a}$ & $I^{2}$ \\
\hline Total & $774 / 841$ & $0.72(0.54-0.96)$ & 0.282 & 20.1 & $0.74(0.58-0.94)$ & 0.533 & 0 & $0.73(0.58-0.91)$ & 0.368 & 7.5 & $0.90(0.71-1.13)$ & 0.465 & 0 & $0.84(0.71-1.01)$ & 0.190 & 32.8 \\
\hline \multicolumn{17}{|l|}{ RACE } \\
\hline Asian & $368 / 416$ & $0.61(0.40-0.93)$ & 0.670 & 0 & $0.67(0.49-0.93)$ & 0.358 & 0 & $0.66(0.49-0.89)$ & 0.593 & 0 & $0.83(0.58-1.18)$ & 0.257 & 22.1 & $0.78(0.64-0.96)$ & 0.681 & 0 \\
\hline Caucasian & $406 / 425$ & $0.83(0.46-1.23)$ & 0.175 & 39.5 & $0.83(0.57-1.19)$ & 0.460 & 0 & $0.81(0.58-1.14)$ & 0.232 & 30 & $0.95(0.70-1.29)$ & 0.395 & 0 & $0.87(0.64-1.18)$ & 0.103 & 51.5 \\
\hline
\end{tabular}

$P^{2}: 0-25$, no heterogeneity; 25-50, modest.

${ }^{\mathrm{a}} P$ value of $\mathrm{Q}$-test for heterogeneity test.

Bold numbers mean statistically significant results. 
Table 3 Stratification analyses of genetic susceptibility of rs9340799 polymorphism to male infertility

\begin{tabular}{|c|c|c|c|c|c|c|c|c|c|c|c|c|c|c|c|c|}
\hline \multirow[t]{2}{*}{ Category } & \multirow{2}{*}{$\begin{array}{l}\text { Cases/ } \\
\text { controls }\end{array}$} & \multicolumn{3}{|c|}{ AA vs. GG } & \multicolumn{3}{|c|}{ GA vs. GG } & \multicolumn{3}{|c|}{$A A+G A$ vs. GG } & \multicolumn{3}{|c|}{$A A$ vs. $G A+G G$} & \multicolumn{3}{|c|}{ A allele vs. $\mathrm{G}$ allele } \\
\hline & & OR(95\% Cl) & $P^{a}$ & $I^{2}$ & OR(95\% Cl) & $P^{a}$ & $I^{2}$ & $\mathrm{OR}(95 \% \mathrm{Cl})$ & $P^{a}$ & $I^{2}$ & OR(95\% Cl) & $P^{\mathrm{a}}$ & $I^{2}$ & $\mathrm{OR}(95 \% \mathrm{Cl})$ & $P^{a}$ & $I^{2}$ \\
\hline Total & $774 / 841$ & $1.67(1.21-2.32)$ & 0.392 & 3.9 & $1.03(0.76-1.39)$ & 0.764 & 0 & $1.27(0.96-1.68)$ & 0.796 & 0 & $1.63(1.32-2.03)$ & 0.077 & 49.7 & $1.39(1.13-1.68)$ & 0.172 & 35.3 \\
\hline \multicolumn{17}{|l|}{ RACE } \\
\hline Asian & $368 / 416$ & $1.56(0.93-2.62)$ & 0.714 & 0 & $0.81(0.49-1.34)$ & 0.524 & 0 & $1.13(0.71-1.82)$ & 0.952 & 0 & $1.93(1.42-2.62)$ & 0.768 & 0 & $1.49(1.18-1.86)$ & 0.375 & 0 \\
\hline Caucasian & $406 / 425$ & $1.75(1.15-2.68)$ & 0.174 & 39.7 & $1.17(0.81-1.71)$ & 0.847 & 0 & $1.35(0.95-1.92)$ & 0.569 & 0 & $1.38(1.02-1.88)$ & 0.062 & 59.2 & $1.39(0.97-1.81)$ & 0.109 & 50.5 \\
\hline
\end{tabular}

${ }^{\mathrm{a}} P$ value of $\mathrm{Q}$-test for heterogeneity test.

$P^{2}: 0-25$, no heterogeneity; 25-50, modest heterogeneity; 50, high heterogeneity.

Bold numbers mean statistically significant results. 
Table 4 Stratification analyses of genetic susceptibility of rs1256049 polymorphism to male infertility

\begin{tabular}{|c|c|c|c|c|c|c|c|c|c|c|c|c|c|c|c|c|}
\hline \multirow[t]{2}{*}{ Category } & \multirow[t]{2}{*}{ Cases/Controls } & \multicolumn{3}{|c|}{ AA vs. GG } & \multicolumn{3}{|c|}{ GA vs. GG } & \multicolumn{3}{|c|}{$A A+G A$ vs. $G G$} & \multicolumn{3}{|c|}{$A A$ vs. $G A+G G$} & \multicolumn{3}{|c|}{$A$ allele vs. $\mathrm{G}$ allele } \\
\hline & & OR(95\% Cl) & $P^{\mathrm{a}}$ & $1^{2}$ & OR(95\% Cl) & $P^{a}$ & $I^{2}$ & OR(95\% Cl) & $P^{\mathrm{a}}$ & $I^{2}$ & OR(95\% Cl) & $P^{a}$ & $1^{2}$ & OR(95\% Cl) & $P^{\mathrm{a}}$ & $I^{2}$ \\
\hline Total & 1378/1478 & $0.57(0.32-1.01)$ & 0.940 & 0 & $1.59(1.12-2.25)^{b}$ & 0.047 & 50.9 & $1.30(1.05-1.61)$ & 0.075 & 45.7 & $0.55(0.32-0.96)$ & 0.920 & 0 & $1.29(0.97-1.72)$ & 0.068 & 46.9 \\
\hline \multicolumn{17}{|l|}{ RACE } \\
\hline Asian & 1056/991 & $0.57(0.32-1.01)$ & 0.853 & 0 & $1.52(1.00-2.31)^{\mathrm{b}}$ & 0.038 & 60.6 & $1.23(0.98-1.56)$ & 0.064 & 55 & $0.55(0.31-0.97)$ & 0.818 & 0 & $1.19(0.86-1.65)$ & 0.067 & 54.4 \\
\hline Caucasian & $322 / 487$ & $0.64(0.03-15.86)$ & - & - & $1.87(0.92-3.80)$ & 0.208 & 36.2 & $1.74(1.03-2.94)$ & 0.275 & 22.6 & $0.58(0.02-14.38)$ & - & - & $1.66(0.99-2.77)$ & 0.372 & 0 \\
\hline
\end{tabular}

a $P$ value of Q-test for heterogeneity test.
b Random-effects model was used when a $P$ value, 0.05 for heterogeneity test; otherwise, fixed-effects model was used.

${ }^{\mathrm{b}}$ Random-effects model was used when a $P$ value, 0.05 for heterogeneity test; other
$P^{2}: 0-25$, no heterogeneity; $25-50$, modest heterogeneity; 50 , high heterogeneity.

Bold numbers mean statistically significant results. 


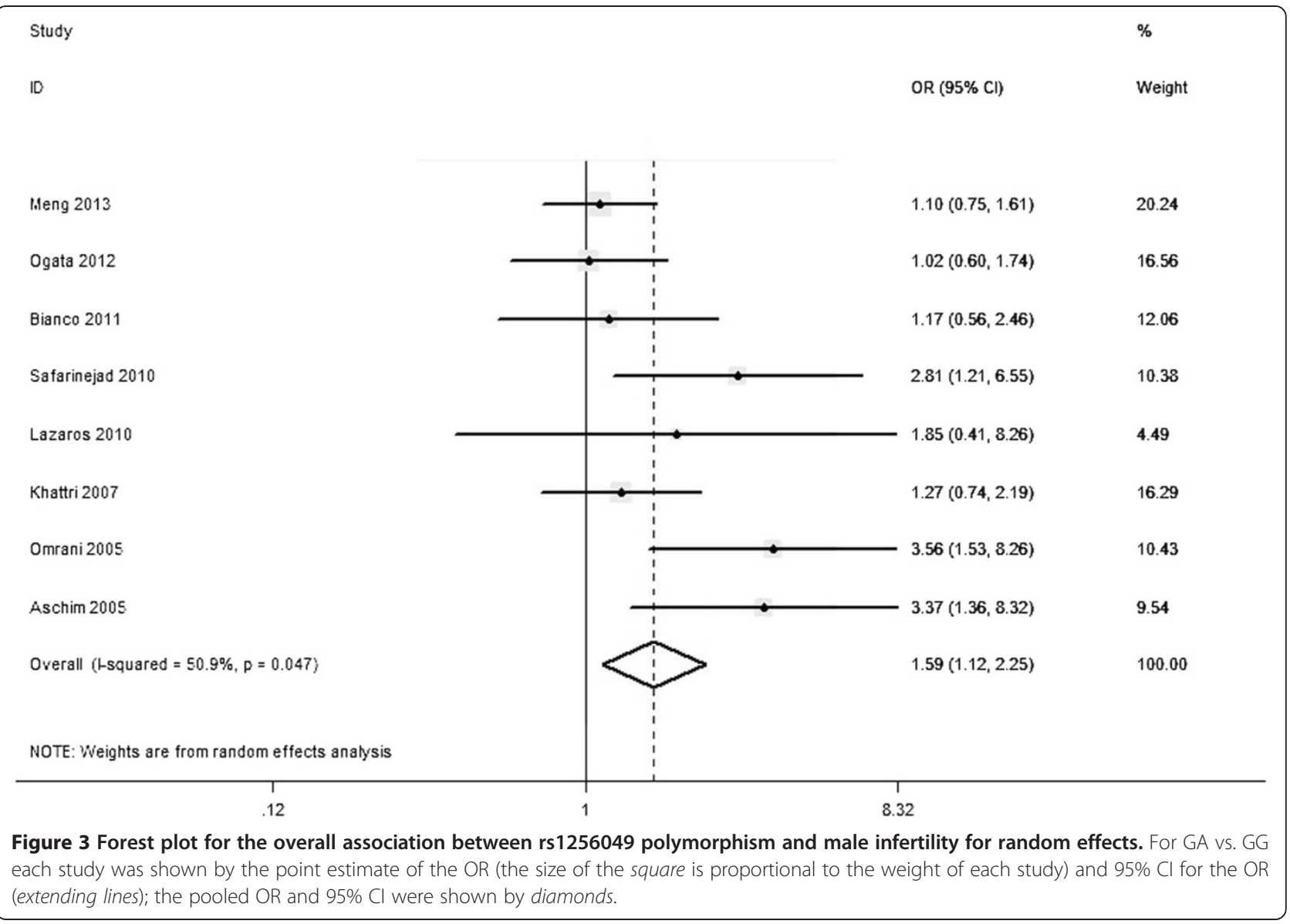

implemented. Trimming was based on fixed-effects model, and the adjusted estimates obtained by using the random effects model were ORs of 1.17 (0.78-1.74) for GA vs. GG and $1.08(0.75-1.54)$ for $\mathrm{AA}+\mathrm{GA}$ vs. GG in the Figure 5. Although Meta-analysis with or without the trim-and-fill method also ends up with same conclusions, but the ORs were not statistically significant difference. So it was indicated that the results of these studies were not statistically robust.

\section{Discussion}

The present meta-analysis, including 1568 cases and 1602 controls from 10 case control studies, explored the association between the ERs polymorphisms and male infertility. The results indicated that rs2234693C allele was associated with decreased risk of the male infertility, particularly in the Asian population. In contrast, rs9340799AA genotype was observed as a risk factor for infertility in both Asian and Caucasian population, and rs1256049GA genotype was associated with an increased risk for developing male sterility. However, the rs4986938 polymorphism was not associated with male infertility. In addition, we tried to find the data in the available database, such as PUBMED [32], National Human Genome Research Institute GWAS Catalog [33] and GWAS Central [34], but we found no relevant genome-wide association (GWAS) study about these four polymorphisms.

Estradiol has been reported as a survival factor for germ cells [11], involving in the induction of oxidative DNA damage, and the aberrant level of estrogen may lead to impaired sperm production [35-37]. It has been shown that free radicals inhibit steriodogenesis by interfering with cholesterol transport to the mitochondria and/or the catalytic function of P450 enzymes, which leads to an increase in lipid per oxidation and decline in the antioxidant barrier [38]. Moreover, estrogens can regulate mitochondrial function by increasing nuclear respiratory factor-1 (NRF-1) expression [5]. Specifically, estradiol stimulates mitochondrial function through a genomic mechanism of ER action involving direct ER $\alpha$ and ER $\beta$ interaction with an oestrogen response element in the NRF-1 promoter [39]. In vivo knockdown experiments have indicated that estradiol stimulates NRF-1 transcription and consequently increases mitochondrial biogenesis through ER $\alpha$ activity but not through ER $\beta$ activity in MCF-7 breast cells [40]. This findings indicates that ER $\alpha$ polymorphisms 

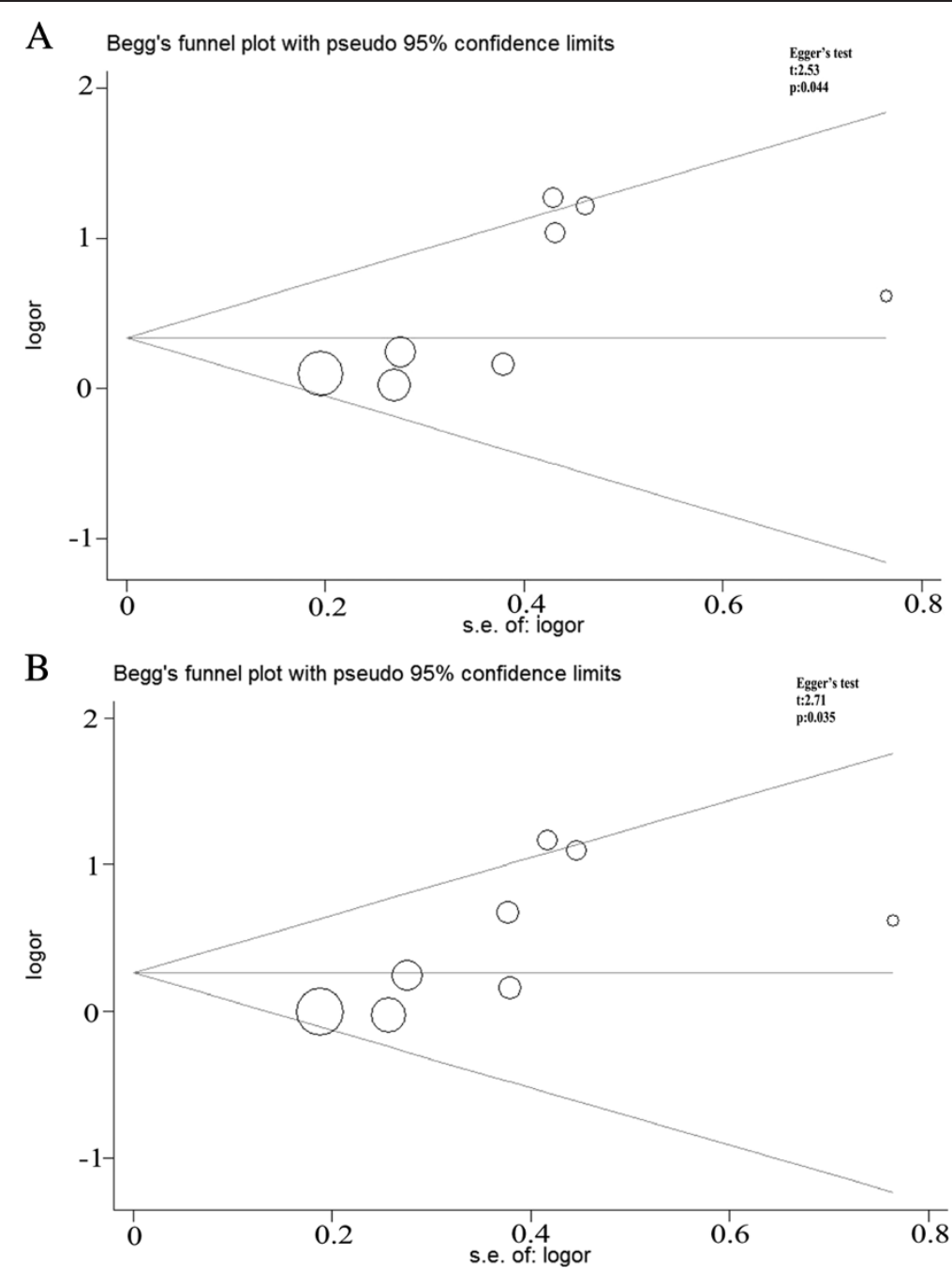

Figure 4 Begg's funnel plot of publication bias test for the rs1256049. (A) GA vs. GG. (B) AA + GA vs. GG. Each point represents a separate study for the indicated association. Log (OR), natural logarithm of OR. Horizontal line means effect size.

can increase mitochondrial activity via NRF-1 transcription in human ejaculated spermatozoa, presenting them with high motility [22].

The mechanisms behind altered ERs function in subjects with polymorphisms remain unclear. The polymorphism rs1256049 located at the splice acceptor site just prior to exon 8 in ER $\beta$ [41] and may potentially affect the splicing of this exon, leading to proteins with different properties than the wild-type ER $\beta[42,43]$. In addition, studies have reported the polymorphism could also have a direct effect through changing the nucleotide sequence and thereby the secondary structure of the ER $\beta$ mRNA, possibly leading to changes the function of mRNA $[44,45]$. It has been reported that ER $\alpha$ gene polymorphisms (rs2234693 and rs9340799) may modalate the effect of oestradiol on CYP19, which encodes aromatase expression, disrupting the gene causes a decline in sperm numbers and loss of male infertility $[46,47]$.
The precise role of estrogen receptors in male fertility status is understood. Some findings suggest that specific polymorphisms of the ER $\alpha$, and ER $\beta$ genes which confer a lower sex hormone binding globulin (SHBG) and thus a stronger unbound estrogen effect, may adversely affect human spermatogenesis [48,49]. SHBG is involved in both delivering reproductive hormones to target tissues and controlling the concentration of androgens and estrogens in the serum and tissues [50]. Pavlovich et al. [51] demonstrated that infertile men with severe oligozoospermia had significantly lower $\mathrm{T}$ (testosterone) and higher E2 (estradiol) concentrations than fertile control subjects, resulting in an elevated T/E2 ratio.

Identifying the source of heterogeneity is one of the most important goals of the meta-analysis. Thus, we stratified the studies only according to ethnicity (because the sources of the controls were selected through populationbased, and the method used was the only one different). 

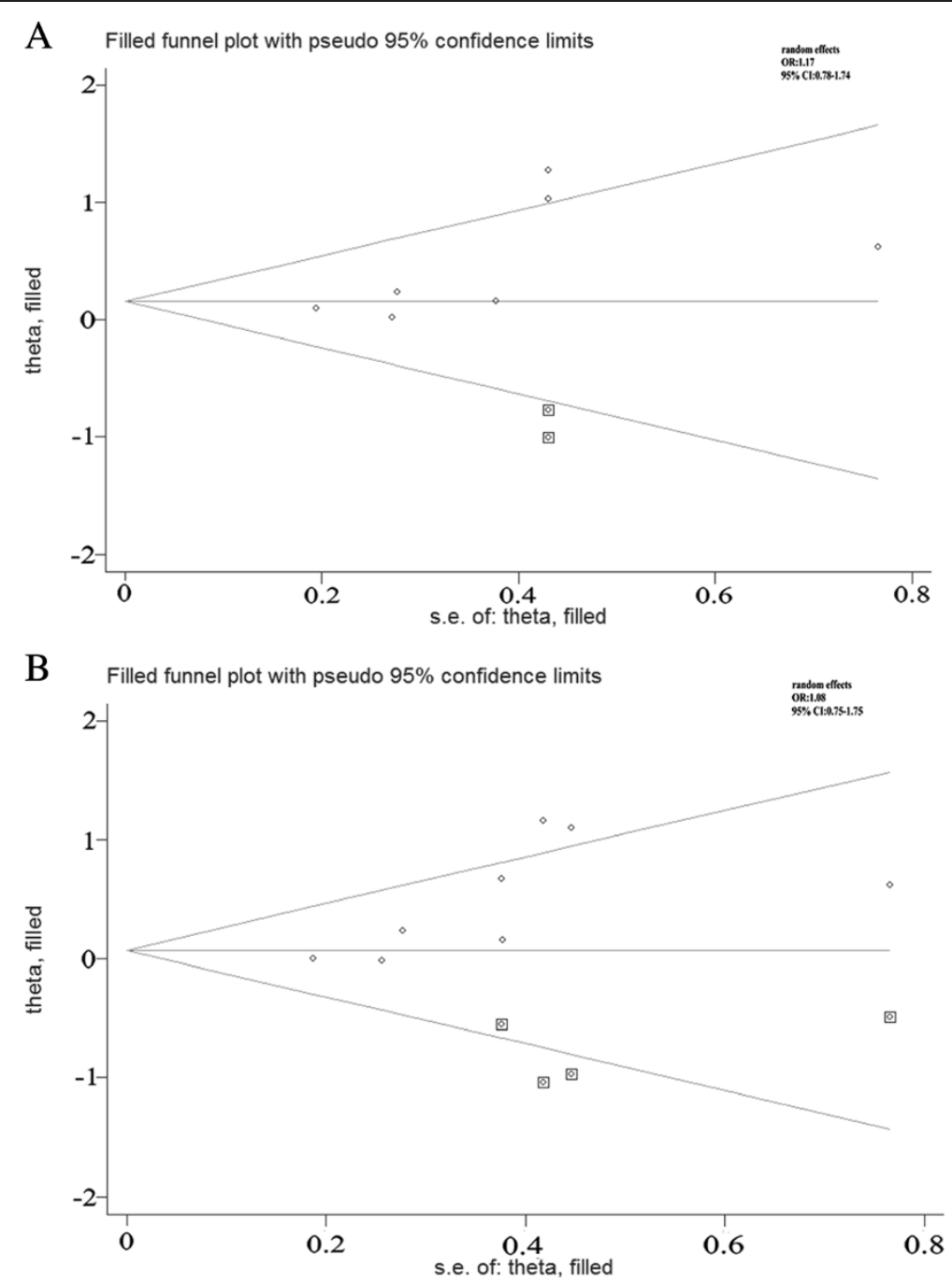

Figure 5 Begg's funnel plot of publication bias test for the rs 1256049 using the trim-and-fill method. (A) GA vs. GG. (B) AA+GA vs. GG. Each point represents a separate study for the indicated association. Log (OR), natural logarithm of OR. Horizontal line means effect size. The adjusted estimates obtained by using the random effects model for GA vs. GG and AA + GA vs. GG.

Stratified analysis by ethnicity revealed that there was no difference between the European population and Asian population, suggesting that different ethnicities and environmental exposures may have no influence on the susceptibility of male infertility, and more studies should be accumulated to reveal the difference. In addition, for the rs1256049, sensitivity analysis revealed that the three independent studies $[7,22,23]$ were the main source of heterogeneity. Heterogeneity was decreased when these studies were removed. For these three studies, the sample size was not sufficient and the numbers of rs1256049AA genotype was both zero. These two points may be the main reason for the heterogeneity in the performed analysis. For the rs1256049, there was obvious evidence of publication bias. As the same with heterogeneity, the numbers of the cases and controls of the wild-type homozygote in these three studies $[7,22,23]$ were too small to keep the results statistically robust, so it maybe the key factor for the bias. Using a proper and representative subject is very important in reducing bias in such genotype association studies.

There are still some limitations in this meta-analysis. Firstly, there were only ten literatures enrolled in this meta-analysis, the sample size was not big enough to have substantial power exploring the real association. Secondly, the detailed information (such as life-style, age, and work) could not be traced, so that our unadjusted estimates should be confirmed by further studies. In addition, an individual with a clinical disorder was not a result of the single gene that is disrupted, but that the genetic disruption was embedded within the context of that individual's entire genome and environment exposure [52]. In fact, some other genes related to fertility could also play an important role in spermatogenesis. 


\section{Conclusions}

In summary, this meta-analysis suggested that the rs2234693C allele was the protective factor for male infertility, the rs9340799AA genotype was associated with an increased risk for infertility, and the rs1256049GA genotype was also the negative factor.

\section{Additional file}

Additional file 1: Text S1. The reasons for exclusion of the articles which were shown in Figure 1.

\section{Abbreviations}

Cl: Confidence interval; E2: Estradiol; ERs: Estrogen receptors; NR: Nuclear receptor; NRF-1: Nuclear respiratory factor-1; OR: Odds ratio; PCRRFLP: Polymerase chain reaction-restriction fragment length polymorphism; SHBG: Sex hormone binding globulin; SNPs: Single nucleotide polymorphisms; T: Testosterone; vs.: Versus.

\section{Competing interests}

The authors declare that they have no competing interests.

\section{Authors' contributions}

TFL and XYX conceived and designed the experiments. WWL, QYW, NL, CZ, $X J L$ and YXC performed the experiments. TFL and QYW analyzed the data. TFL and XYX wrote the paper. All authors read and approved the final manuscript.

\section{Acknowledgments}

We appreciate Dr. Bang-Shun He, Central Laboratory, Nanjing First Hospital, Nanjing Medical University, Jiangsu, China, for his critical review, scientific editing of the manuscript and constructive comments. This work was supported by Natural Science Foundation of Jiangsu Province (BK2011660) and Key Foundation of Jiangsu Science and Technology Bureau (BM2013058).

Received: 21 April 2014 Accepted: 9 August 2014

Published: 16 August 2014

\section{References}

1. De Kretser D, Baker H: Infertility in men: recent advances and continuing controversies. J Clin Endocrinol Metab 1999, 84:3443-3450.

2. Dohle GR, Colpi G, Hargreave T, Papp G, Jungwirth A, Weidner W: EAU guidelines on male infertility. Eur Urol 2005, 48:703-711.

3. Pieri PC, Pereira DH, Glina S, Hallak J, McElreavey K, Moreira-Filho CA: A cost-effective screening test for detecting AZF microdeletions on the human Y chromosome. Genet Test 2002, 6:185-194.

4. Ferlin A, Arredi B, Foresta C: Genetic causes of male infertility. Reprod Toxicol 2006, 22:133-141.

5. Zalata A, Abdalla H, El-Bayoumy $Y$, Mostafa T: Oestrogen receptor alpha gene polymorphisms relationship with semen variables in infertile men Andrologia 2014, 46:618-624.

6. Carreau S, Lambard S, Delalande C, Denis-Galeraud I, Bilinska B, Bourguiba S: Aromatase expression and role of estrogens in male gonad: a review. Reprod Biol Endocrinol 2003, 1:35.

7. Bianco B, Peluso C, Gava MM, Ghirelli-Filho M, Lipay MVN, Lipay MA, Christofolini DM, Barbosa CP: Polymorphisms of estrogen receptors alpha and beta in idiopathic, infertile Brazilian men: a case-control study. Mol Reprod Dev 2011, 78:665-672

8. Zhai J, Lanclos K, Abney T: Estrogen receptor messenger ribonucleic acid changes during Leydig cell development. Biol Reprod 1996, 55:782-788.

9. Delbès $G$, Levacher $C$, Duquenne $C$, Racine $C$, Pakarinen $P$, Habert R: Endogenous estrogens inhibit mouse fetal Leydig cell development via estrogen receptor alpha. Endocrinology 2005, 146:2454-2461.

10. Atanassova N, McKinnell C, Walker M, Turner K, Fisher J, Morley M, Millar M, Groome N, Sharpe R: Permanent effects of neonatal estrogen exposure in rats on reproductive hormone levels, sertoli cell number, and the efficiency of spermatogenesis in adulthood. Endocrinology 1999 140:5364-5373.
11. Pentikäinen V, Erkkilä K, Suomalainen L, Parvinen M, Dunkel L: Estradiol acts as a germ cell survival factor in the human testis in vitro. $J$ Clin Endocrinol Metab 2000, 85:2057-2067.

12. Gould M, Hurst $P$, Nicholson $H$ : The effects of oestrogen receptors alpha and beta on testicular cell number and steroidogenesis in mice. Reproduction 2007, 134:271-279.

13. El-Shafei M, Mostafa M, Mostafa T: Oestrogen receptors in the developing rat prostate. Andrologia 2011, 43:94-99.

14. Filipiak E, Suliborska D, Laszczynska M, Walczak-Jedrzejowska R, Oszukowska E, Marchlewska K, Kula K, Slowikowska-Hilczer J: Estrogen receptor alpha localization in the testes of men with normal spermatogenesis. Folia Histochem Cytobiol 2012, 50:340-345.

15. Menasce LP, White GR, Harrison CJ, Boyle JM: Localization of the estrogen receptor locus (ESR) to chromosome $6 \mathrm{q} 25.1$ by FISH and a simple post-FISH banding technique. Genomics 1993, 17:263-265.

16. Ogawa S, Inoue S, Watanabe T, Hiroi H, Orimo A, Hosoi T, Ouchi $Y$, Muramatsu M: The complete primary structure of human estrogen receptor beta (hERbeta) and its heterodimerization with ER alpha in vivo and in vitro. Biochem Biophys Res Commun 1998, 243:122-126.

17. Enmark E, Pelto-Huikko M, Grandien K, Lagercrantz S, Lagercrantz J, Fried G, Nordenskjöld M, Gustafsson JA: Human estrogen receptor $\beta$-gene structure, chromosomal localization, and expression pattern. $J$ Clin Endocrinol Metab 1997, 82:4258-4265.

18. Gennari L, Merlotti D, De Paola V, Calabro A, Becherini L, Martini G, Nuti R: Estrogen receptor gene polymorphisms and the genetics of osteoporosis: a HuGE review. Am J Epidemiol 2005, 161:307-320.

19. Meng J, Mu X, Wang $Y$ : Influence of the Xbal polymorphism in the estrogen receptor-a gene on human spermatogenic defects. Genet $\mathrm{Mol}$ Res 2013, 12:1808-1815.

20. Ogata T, Fukami M, Yoshida R, Nagata E, Fujisawa Y, Yoshida A, Yoshimura $Y$ : Haplotype analysis of ESR2 in Japanese patients with spermatogenic failure. J Hum Genet 2012, 57:449-452.

21. Safarinejad MR, Shafiei N, Safarinejad S: Association of polymorphisms in the estrogen receptors alpha, and beta (ESR1, ESR2) with the occurrence of male infertility and semen parameters. J Steroid Biochem Mol Biol 2010, 122:193-203.

22. Lazaros LA, Xita NV, Kaponis Al, Zikopoulos KA, Plachouras NI, Georgiou IA: Estrogen receptor $\alpha$ and $\beta$ polymorphisms Are associated with semen quality. J Androl 2010, 31:291-298.

23. Khattri A, Pandey R, Gupta N, Chakravarty B, Deendayal M, Singh L, Thangaraj $K$ : CA repeat and Rsal polymorphisms in ER $\beta$ gene are not associated with infertility in Indian men. Int J Androl 2009, 32:81-87.

24. Omrani M, Samadzadae S, Farshid B, Jahandidae B, Yazdanpanah K: Is there any association between ER gene polymorphism and infertility in Iranian men? J Res Med Sci 2006, 11:48-52.

25. Aschim EL, Giwercman A, Ståhl O, Eberhard J, Cwikiel M, Nordenskjöld A, Haugen TB, Grotmol T, Giwercman YL: The Rsal polymorphism in the estrogen receptor- $\beta$ gene is associated with male infertility. J Clin Endocrinol Metab 2005, 90:5343-5348.

26. Kukuvitis A, Georgiou I, Bouba I, Tsirka A, Giannouli C, Yapijakis C, Tarlatzis B, Bontis J, Lolis D, Sofikitis N: Association of oestrogen receptor a polymorphisms and androgen receptor CAG trinucleotide repeats with male infertility: a study in 109 Greek infertile men. Int J Androl 2002, 25:149-152.

27. Higgins J, Thompson SG, Deeks JJ, Altman DG: Measuring inconsistency in meta-analyses. BMJ 2003, 327:557-560.

28. Midgette AS, Wong JB, Beshansky JR, Porath A, Fleming C, Pauker SG: Cost-effectiueness of streptokinase for acute myocardial infarction a combined meta-analysis and decision analysis of the effects of infarct location and of likelihood of infarction. Med Decis Making 1994, 14:108-117.

29. Egger M, Smith GD, Schneider M, Minder C: Bias in meta-analysis detected by a simple, graphical test. BMJ 1997, 315:629-634.

30. Hardy-Weinberg Equilibrium. Website title [http://ihg.gsf.de/cgi-bin/hw/hwa1.pl]

31. Duval S, Tweedie R: Trim and fill: A simple funnel-plot-based method of testing and adjusting for publication bias in meta-analysis. Biometrics 2000, 56:455-463.

32. PubMed. Website title [http://www.ncbi.n/m.nih.gov/pubmed]

33. NHGRI GWAS Catalog. Website title [http://www.genome.gov/26525384]

34. GWAS Central. Website title [http://www.gwascentral.org/]

35. Couse JF, Korach KS: Estrogen receptor null mice: what have we learned and where will they lead us? Endocr Rev 1999, 20:358-417. 
36. Carreau S, Delalande C, Silandre D, Bourguiba S, Lambard S: Aromatase and estrogen receptors in male reproduction. Mol Cell Endocrinol 2006 246:65-68.

37. Watson CE, Gauthier SY, Davies PL: Structure and expression of the highly repetitive histone $\mathrm{H} 1$-related sperm chromatin proteins from winter flounder. Eur J Biochem 1999, 262:258-267.

38. Hamden K, Silandre D, Delalande C, ElFeki A, Carreau S: Protective effects of estrogens and caloric restriction during aging on various rat testis parameters. Asian J Androl 2008, 10:837-845.

39. Mattingly KA, Ivanova MM, Riggs KA, Wickramasinghe NS, Barch MJ, Klinge CM: Estradiol stimulates transcription of nuclear respiratory factor-1 and increases mitochondrial biogenesis. Mol Endocrinol 2008, 22:609-622.

40. Försti A, Zhao C, Israelsson E, Dahlman-Wright K, Gustafsson J-Å, Hemminki $K:$ Polymorphisms in the estrogen receptor beta gene and risk of breast cancer: no association. Breast Cancer Res Treat 2003, 79:409-413.

41. Ogawa S, Inoue S, Watanabe T, Orimo A, Hosoi T, Ouchi Y, Muramatsu M: Molecular cloning and characterization of human estrogen receptor $\beta c x$ : a potential inhibitor of estrogen action in human. Nucleic Acids Res 1998, 26:3505-3512.

42. Peng B, Lu B, Leygue E, Murphy L: Putative functional characteristics of human estrogen receptor-beta isoforms. J Mol Endocrinol 2003, 30:13-29.

43. Shen LX, Basilion JP, Stanton VP: Single-nucleotide polymorphisms can cause different structural folds of mRNA. Proc Natl Acad Sci 1999, 96:7871-7876.

44. lida $\mathrm{K}$, Akashi $\mathrm{H}$ : A test of translational selection at 'silent' sites in the human genome: base composition comparisons in alternatively spliced genes. Gene 2000, 261:93-105.

45. Kinoshita Y, Chen S: Induction of aromatase (CYP19) expression in breast cancer cells through a nongenomic action of estrogen receptor alpha. Cancer Res 2003, 63:3546-3555.

46. Carreau S, Bouraima-Lelong H, Delalande C: Estrogen, a female hormone involved in spermatogenesis. Adv Med Sci 2012, 57:31-36.

47. Robertson KM, O'Donnell L, Jones ME, Meachem SJ, Boon WC, Fisher CR, Graves KH, McLachlan Rl, Simpson ER: Impairment of spermatogenesis in mice lacking a functional aromatase (cyp 19) gene. Proc Natl Acad Sci 1999, 96:7986-7991.

48. Westberg L, Baghaei F, Rosmond R, Hellstrand M, Landén M, Jansson M, Holm G, Björntorp P, Eriksson E: Polymorphisms of the androgen receptor gene and the estrogen receptor beta gene are associated with androgen levels in women. J Clin Endocrinol Metab 2001, 86:2562-2568.

49. Ascenzi P, Bocedi A, Marino M: Structure-function relationship of estrogen receptor alpha and beta: impact on human health. Mol Aspects Med 2006, 27:299-402.

50. Hammond GL: Access of reproductive steroids to target tissues. Obstet Gynecol Clin North Am 2002, 29:411-423.

51. Pavlovich CP, King P, Goldstein M, Schlegel PN: Evidence of a treatable endocrinopathy in infertile men. J Urol 2001, 165:837-841.

52. Dipple KM, Phelan JK, McCabe ER: Consequences of complexity within biological networks: robustness and health, or vulnerability and disease. Mol Genet Metab 2001, 74:45-50.

doi:10.1186/1477-7827-12-79

Cite this article as: Li et al:: Polymorphisms in estrogen receptors predict the risk of male infertility: a meta-analysis. Reproductive Biology and Endocrinology 2014 12:79.

\section{Submit your next manuscript to BioMed Central and take full advantage of:}

- Convenient online submission

- Thorough peer review

- No space constraints or color figure charges

- Immediate publication on acceptance

- Inclusion in PubMed, CAS, Scopus and Google Scholar

- Research which is freely available for redistribution

Submit your manuscript at www.biomedcentral.com/submit
C Biomed Central 